\title{
Sobre os fins morais da razão
}

\author{
About the moral ends of reason
}

\section{Ricardo Machado Santos*}

Instituto Federal de Ciência e Tecnologia de Mato Grosso do sul (IFMS), Jardim, MS

\section{Resumo}

O objetivo do presente artigo é fazer uma exposição sumária dos resultados obtidos em minha tese de doutorado, defendida e aprovada no Instituto de Filosofia e Ciências Humanas da Unicamp no dia 09 de junho de 2015. Assim, se apresenta resumidamente a discussão sobre a necessidade dos chamados "fins morais da razão" dentro da filosofia kantiana. Tal investigação propunha explicitar algumas modificações apresentadas na ética de Kant dos textos da década de 1780 aos seus textos tardios da segunda metade da década de 1790, mostrando que elas vão no sentido de uma sensificação da ética kantiana e que esta só é possível à medida que Kant substitui conceitos de origem cristã (Deus, santidade, sumo bem) notadamente comprometidos com um domínio da transcendência por conceitos de origem grega (virtude, ascese moral, autoconstrução moral, etc.) mais ligados ou mais passíveis de serem vinculados à natureza humana.

Palavras-chave: Kant. Ética. Virtude. Antropologia.

* RMS: Doutor em filosofia, e-mail: ricardo.macs43@gmail.com 


\section{Abstract}

The purpose of this article is to make a summary of the results in my doctoral thesis, defended and approved at the Unicamp Institute of Philosophy and Human Sciences on June 9, 2015. Thus, it summarizes the discussion of the need for called "moral ends of reason" within the Kantian philosophy. This research proposed to explain some modifications made in the ethics of Kant of the texts of the 1780s to his later texts the second half of the 1790s, showing that they are going towards a sensification of Kantian ethics and this is only possible as Kant replaces concepts of Christian origin (God, holiness, supreme good) especially committed to a field of transcendence by concepts of Greek origin (virtue, moral asceticism, moral self-construction, etc.) on or more likely to be linked to nature human.

Keywords: Kant. Ethics. Virtue. Antropology.

\section{Introdução}

Kant sempre deixou claro sua tese de que o homem deve progredir em busca do melhor, ou seja, tanto na sua filosofia político-jurídica como na sua ética. Há a tese de que a razão manda alcançar fins (como uma constituição política perfeita, a paz perpétua, a santidade, a virtude, etc.) que representam um maximum, uma perfeição, e que servem de meta para os esforços humanos.

Ou seja, por um lado temos: a) a razão que nos prescreve fins, ideias, que não permitem sua plena realização, sua efetivação empírica, mas apenas uma aproximação constante, haja vista que ideias são por definição conceitos que não encontram correspondente na experiência, isto é, conceitos aos quais nenhuma intuição lhe pode ser adequada.

A razão nos prescreve tais fins ou ideias em forma de regras, comandos; sendo assim, é necessário pensar, além da razão: b) alguém que execute tais regras, vale dizer, é necessário pensar um executor; mas como os fins que a razão impõe são diversos, são diferentes os tipos de executores. Assim por exemplo, a ideia de perfeição moral ou natural (ou se quiser a regra que prescreve que se busque tais fins) deve 
ser executada pelo indivíduo (como vemos na Doutrina da virtude); já a ideia de uma república perfeita ou de paz perpétua, por mais estranho que isso possa soar, tem como executores uma determinada comunidade (como vemos na terceira parte de $A$ Religião nos limites da simples razão) ou a humanidade como um todo (como vemos na Ideia de uma história universal de um ponto de vista cosmopolita ou em À Paz Perpétua).

Em terceiro lugar, podemos pensar: c) o movimento que conduz o executor da regra da razão ao fim prescrito pela mesma, isto é, podemos pensar o progresso rumo à realização, ou melhor, à aproximação das ideias propostas pela razão.

O objetivo geral de minhas pesquisas é mostrar que há uma dinâmica interna ao pensamento kantiano, ou seja, há uma modificação no modo como Kant articula estes pontos (fim da razão, executor, e progresso do executor rumo ao fim) ao longo do seu pensamento e que essa modificação vai sempre no sentido de uma sensificação dos conceitos e princípios práticos, de modo que tanto os fins da razão, quanto o movimento até eles, o progresso, é pensado de forma menos metafísica, estando assim mais adequados (exequíveis) ao executor entendido como homem (terráqueo).

Quando afirmo que há uma sensificação dos conceitos e princípios práticos no pensamento tardio kantiano, faço referência à tese de que Kant procura mostrar que eles não são quiméricos, que são exequíveis, e neste sentido ele precisa abandonar e/ou substituir conceitos de cunho transcendente ou suprassensível, por outros que possam ser mostrados efetivos a partir da sua ligação com a natureza humana.

Assim, por exemplo, no que se refere ao progresso político do gênero humano, ou seja, no movimento que a humanidade faz para alcançar fins políticos, verificamos que a do texto Ideia de uma história universal de um ponto de vista cosmopolita de 1784 ao Conflito das faculdades de 1798, várias mudanças ocorrem, dentre as quais podemos citar o abandono do conceito de uma natureza/providência como motor desse progresso, de modo que a garantia do progresso político não é mais colocada num plano oculto da natureza, mas num signum histórico, na disposição moral do homem. 
No presente texto, no entanto, meu foco principal é mostrar qual é, propriamente, a mudança no que se refere ao conceito de perfeição moral do indivíduo de 1788 a 1797, seja na própria concepção acerca do que seja esta perfeição como no progresso até ela, mostrando que tal mudança não é apenas uma abordagem diferente sobre o mesmo tema, mas que na base dessa mudança estava uma modificação da filosofia prática como um todo, uma vez que coloca o homem vale dizer, o homem no mundo, o terráqueo, e não mais a vontade pura, ou o ser racional em geral, como centro da sua filosofia. Ressaltando que na filosofia do Kant tardio o progresso, o movimento de aproximação aos fins prescritos pela razão, bem como os próprios fins da razão são pensados em termos do homem como cidadão (habitante) do mundo, pode e deve fazer de si mesmo e não da adoção de conceitos metafísicos como providência ou imortalidade da alma (ainda que tomados enquanto princípios regulativos, como objetos de mera fé racional).

Além disso, procuro mostrar, ao longo do presente texto, as várias implicações que as referidas mudanças no pensamento de Kant trazem para sua ética, dentre as quais a principal dela é a substituição de conceitos filosóficos cristãos por gregos. Este inclusive, é um ponto central no meu trabalho: o Kant tardio, em sua ética, é um "Kant grego", ou pelo menos, muito mais grego do que cristão.

Todo meu trabalho, no fim das contas, gira em torno do conceito de fins da razão, ou mais especificamente, os fins morais da razão, os fins éticos. Assim, aqui pretendo discutir a justificação dos mesmos dentro da filosofia prática kantiana (por quais razões é preciso se assumir fins? Ou, com que direito a razão me os impõe?), bem como as mudanças apresentadas no pensamento tardio, tanto na função como na própria concepção dos referidos fins.

É importante deixar claro, também, que para desenvolver alguns dos referidos pontos, tomo como pano de fundo, de um modo ou de outro, a interpretação semântica de Zeljko Loparic. Por isso, elenco a seguir algumas importantes teses que podem ajudar a compreender o meu ponto.

Sabemos que o principal objetivo de Kant em sua filosofia moral, e na verdade a sua grande realização nesta área é a fundamentação do 
princípio supremo da moralidade. Segundo Loparic, podemos dizer que a solução deste problema (fundamentação do princípio supremo da moralidade) supõe dois passos ou etapas: $1^{\circ}$ ) explicitar sua formulação, isto é, a determinação de qual é o juízo sintético a priori fundamental da moralidade; e ${ }^{2}$ ) mostrar como tal juízo é possível e até mesmo efetivo, ou seja, se ele não é um juízo quimérico e que efetivamente vigora. Ou seja, podemos dizer que os passos de Kant são primeiro estabelecer qual o juizo prático sintético a priori supremo e depois mostrar como ele é possível, ou seja, trata-se de fixar e justificar a fórmula da lei moral.

A primeira etapa do problema é resolvida com êxito nas duas primeiras seções da Fundamentação da Metafísica dos Costumes de 1785. A solução da segunda etapa, em contrapartida, embora tentada na terceira seção da referida obra, só será plenamente desenvolvida três anos mais tarde, na Crítica da razão prática.

A fórmula da Lei moral deve ter um caráter incondicional, deve ser um imperativo categórico. "Age apenas segundo uma máxima tal que possas ao mesmo tempo querer que ela se torne uma lei universal" (GMS 4:421). Esta é a versão mais geral do imperativo, da fórmula da lei.

Mas, uma coisa é pensá-la apenas enquanto regra outra é conceber a lei moral também como força, isto é, a simples descoberta de um princípio universal para as ações, não é ainda uma prova de que ele seja possível e mesmo efetivo. Ainda que todo ser racional reconheça o imperativo categórico como lei moral universal isso não significa que ela tenha força para mover o homem a agir, que ela efetivamente obrigue, que constranja a vontade do homem. Ou seja, descoberto o juízo sintético prático a priori resta a questão: como ele é possível?

A fórmula da lei conecta um conceito do sujeito (a vontade humana) com um conceito do predicado (a condição formal do seu agir). [...] Como no caso de qualquer outro juízo sintético, a priori ou a posteriori, deve existir um "terceiro elemento" que permita juntar o conceito de sujeito (minha vontade) e o de predicado (universalizabilidade das normas). Ora, esse terceiro elemento só pode ser, pensa Kant, um conceito positivo de liberdade. Entretanto, como a razão teórica possui apenas um conceito negativo da liberdade, a lei que liga a minha vontade com a 
universalizabilidade das normas permanece sem fundamento possível. Kant está num impasse e se vê na contingência de concluir que a sua tentativa de estabelecer a possibilidade e a verdade da lei moral fracassou porque não podia deixar de fracassar. (LOPARIC, 1999, p. 30-31)

Segundo Loparic, Kant acaba não conseguindo dar uma resposta adequada ao problema em 1785, identificando erroneamente o terceiro elemento, que faria a síntese entre sujeito e predicado, com "a condição ontológica que torna possível a ação em conformidade com essa fórmula, a saber, com a liberdade da vontade", confundindo um problema semântico com um metafísico.

Em contrapartida, na Crítica da razão prática, a posição de Kant é totalmente diferente. Ele mostra que a liberdade é a ratio essendi da moralidade. De modo que, o terceiro elemento procurado para assegurar a realidade da fórmula da lei moral, não pode ser nem a liberdade, nem qualquer outra condição suprassensível. O terceiro elemento, portanto, tem que ser algo sensível, mas não um dado a posteriori.

Assim, Kant no texto de 1788, tenta mostrar que a razão pura pode ser prática, o que significa, segundo Loparic, que deve ser possível explicitar para ela um domínio sensível. Ao mostrar que a lei moral, a razão pura produz efeitos sensíveis, vale dizer, o sentimento de respeito que surge a partir da consciência da lei moral (fato da razão), Kant mostra que ela efetivamente vigora, que ela não é uma quimera, e, por conseguinte, mostra que sua fórmula (o juízo sintético a priori prático fundamental) é possível, pois, tudo que é efetivo é possível.

Em suma, a resposta kantiana para a pergunta de como é possível a fórmula da lei moral, na Crítica da razão prática, consiste em dizer que ela é possível porque é efetiva, e sua efetividade é atestada pelo fato da razão, isto é, pelo efeito que nossa razão produz sobre a nossa sensibilidade moral, o que implica no reconhecimento de um domínio de sensificação prático, distinto do teórico. (1999, p. 35 e ss.).

Após isso, no desenvolvimento de seu pensamento, Kant amplia seu projeto, continuando na tentativa de sensificação de outros conceitos e juízos práticos, sejam éticos, jurídicos e mesmo da filosofia da história. Tal é o que ocorre, também com os fins morais da razão, o que 
justifica, como veremos, as mudanças de posição de Kant relativamente aos conceitos de perfeição moral e fim objetivo da razão, e o consequente abandono dos conceitos de sumo bem, santidade, imortalidade da alma e o fortalecimento do conceito de virtude no pensamento tardio de Kant.

Para a referida sensificação dos conceitos práticos a antropologia assume papel fundamental, pois do mesmo modo que na tentativa de mostrar que o juízo sintético a priori prático, a fórmula da lei moral, se mostrava possível e efetivo a partir da sua vinculação a características sensíveis (o fato da razão e seu efeito sensível, o sentimento de respeito), portanto antropológicas, o mesmo acontece com os demais conceitos e juízos práticos. Assim, por exemplo, o juízo sintético a priori da história, exposto na segunda seção do texto $O$ conflito das faculdades de 1798, vale dizer, a afirmação de que o gênero humano se encontra em constante progresso para o melhor, segundo as próprias palavras de Kant, se mostra provada (SF 7:85), a partir da sua vinculação a um traço da natureza humana, o entusiasmo, que é, assim como o sentimento de respeito, produzido pela razão (cf. KU 5:121, bem como o Capítulo 7 do presente trabalho).

No pensamento tardio kantiano a possibilidade dos conceitos e juízos práticos é, na medida do possível, assegurada graças à sua vinculação à natureza humana, ou, mais especificamente, a sentimentos, afecções e disposições sensíveis. O próprio conceito de virtude, que será um dos objetos principais de análise no presente trabalho passa por esse processo. Na Doutrina da Virtude, Kant procura mostrar, tanto a possibilidade (realidade objetiva), quanto a efetividade deste conceito. Para isso, além de vincular a doutrina da virtude a uma ascese moral e a uma didática moral (cf. Capítulos 5 e 6), também explicita o que ele vai chamar de "Prenoções estéticas da receptividade do ânimo para os conceitos do dever em geral" (TL 6:399), que no caso são os deveres de virtude. Estas prenoções ou disposições são quatro: sentimento moral, consciência moral, sentimento de amor ao próximo e o sentimento de respeito por si mesmo.

De modo geral, Kant mostra que essas disposições formam as condições subjetivas da receptividade da virtude e "em sua totalidade 
são disposições de ânimo estéticas cuja consciência delas não é de origem empírica, pois só podem resultar da consciência de uma lei moral, como efeito da mesma sobre o ânimo" (TL 6:400). Fica claro, portanto, que Kant procura também na Doutrina da Virtude estabelecer um domínio de sentimentos morais (que, contudo, assim como o respeito e o entusiasmo, não tem origem empírica mas são efeitos da razão) para interpretabilidade e aplicabilidade dos deveres de virtude.

Estas teses são o pano de fundo do presente trabalho. Vale dizer, se parte da ideia de que no pensamento tardio, na década de 1790, Kant se ocupou de sensificar, antropologizar, ou melhor, mostrar que certos juízos e conceitos práticos não são quiméricos, mas se mostram possíveis e efetivos, a partir da sua conexão com a natureza humana. Deste modo, a antropologia passa a exercer um papel que Kant já havia anteriormente antecipado, a saber, de ser a contrapartida da filosofia moral pura (cf. GMS 4:388, TL 6:217 entre outros), analisando a receptividade do homem aos conceitos de dever e lei moral (TL 6:412), bem como os traços da natureza humana que podem favorecer ou atrapalhar a realização da mesma.

Mas, para tanto, defendo que o ponto chave de Kant nos seus escritos tardios, seja substituir a base cristã de sua ética por uma série de conceitos, princípios e reflexões de origem grega, bem como a explicitação de um domínio aberto, infinito para o desenvolvimento do homem.

A virtude como disposição de ânimo brava e alegre e a discussão sobre se há apenas uma ou várias virtudes, têm em comum o fato de serem reflexões provenientes da ética grega. Isso é a letra de Kant. Além desses pontos, ao longo da Doutrina da Virtude, Kant lança mão de vários outros conceitos sabidamente de origem grega: virtude como coragem, autocracia, ideal do sábio, saúde moral, vigor/fortaleza de alma, virtude como honra guerreira, virtude como sabedoria prática, riqueza moral, posse de si mesmo, virtude que recompensa a si mesma, homem virtuoso como senhor de si, domínio de si mesmo (autodomínio), nobreza de caráter, autocontrole, apatia, virtude como disposição tranquila de ânimo, julgamento ou juiz (interno) de si mesmo (tribunal interno da consciência), o princípio do "conhece-te a ti mesmo", ascese 
moral, e didática moral (diálogo socrático e maiêutica); os princípios para busca da saúde e prosperidade moral.

Neste sentido, fica claro que Kant toma como base para desenvolver sua ética o pensamento grego antigo. Mesmo na Religião nos limites da simples razão, ele reconhece que os antigos filósofos morais, "quase esgotaram o que de virtude se pode dizer" (RGV 6:25n). O apreço de Kant pelos filósofos gregos, especialmente no que se refere às reflexões éticas, se faz sentir seja na Crítica da razão prática, seja na Religião nos limites da simples razão, mas principalmente na Doutrina da Virtude. Nestes textos ele faz referências à Sócrates, Platão, Aristóteles, Cínicos, Estóicos, Epicuro e Cícero, e a despeito das várias críticas que Kant eventualmente tece (justamente para acomodar os frutíferos conceitos gregos à sua filosofia prática), fica patente o tom reverente e respeitoso diante do pensamento ético dos "antigos".

Entretanto, diferente do que acontece na Doutrina da Virtude, na Crítica da razão prática e Religião nos limites da simples razão os conceitos gregos são ofuscados por algumas ideias cristãs que ele considera fundamentais, a saber, sumo bem, santidade, imortalidade da alma e Deus como governador moral do mundo. Antes do texto de 1797, portanto, é inconcebível pensar a ética kantiana sem estes conceitos.

Em 1788 Kant deixa claro que santidade é uma ideia cristã, e não só isso, de um ponto de vista filosófico, a moral cristã pode ser representada por ela (cf. KpV 5:127n). Da mesma forma ele afirma que a moral cristã é a única (comparada as doutrinas dos antigos: estóicos, epicuristas, cínicos, etc) a fornecer um conceito de Sumo bem que satisfaz a razão pura prática, a saber, o conceito de Reino de Deus (KpV 5:128). Os outros dois conceitos, existência de Deus e imortalidade da alma são introduzidos na moral de Kant como condições necessárias ao sumo bem (Reino de Deus) e santidade, e, portanto, igualmente decorrem da adoção destes princípios derivados da moral cristã.

É claro que tanto os mencionados conceitos oriundos da ética grega quanto os do cristianismo são incorporados à filosofia kantiana e reinterpretados, isto é, avaliados segundo sua importância no contexto da filosofia prática kantiana, tal como acontece também com o conceito platônico de ideia. Neste sentido Kant faz questão deixar claro a fonte 
dos conceitos, se da ética grega ou dos cristãos, pois ele não quer fundar uma nova ética, mas estabelecer justificações racionais para princípios há muito já "descobertos".

O que podemos discutir aqui, então, é o suposto abandono, na Doutrina da Virtude, dos referidos conceitos cristãos e sua substituição por conceitos da ética grega. Indagando se isso realmente se dá, e quais são as possíveis razões para Kant assim proceder. Argumentarei aqui, que isso se deve a um processo de sensificação que dá maior importância à natureza humana, o que tem como consequência uma progressiva substituição do tratamento da vontade pura pela vontade do homem. Desse modo, tal substituição acontece uma vez que os referidos conceitos cristãos envolvem elementos e são eles próprios mais metafísicos, já os conceitos gregos explicitados na doutrina da virtude kantiana se reportam predominantemente à natureza humana.

Assim, no pensamento tardio de Kant, o fim moral por excelência, a perfeição moral deixa de ser pensada como santidade passa a ser virtude; o movimento que o homem faz na busca da realização deste fim, o seu progresso moral, deixa de ser pensado como um progresso ad infinitum que pressuporia uma imortalidade da alma e passa a depender de uma ascese e de uma didática moral, que Kant desenvolve, segundo o que ele mesmo diz, com inspiração estóica, epicurista e socrática; o sumo bem (reino da graça) que seria o fim máximo para o ser racional, enquanto união do fim moral e natural do homem, perde espaço de modo que na Doutrina da Virtude a conexão entre virtude e felicidade é pensada como analítica, a partir do conceito grego de "virtude que recompensa a si mesma", o que coloca em jogo o conceito de autocontentamento moral.

As modificações acima, presentes no pensamento tardio de Kant, são algumas das que apresentarei e desenvolverei no presente trabalho. Mas acredito que já sirvam para dar uma visão geral de como penso a ética dos escritos tardios de Kant, isto é, não mais como uma racionalização da moral cristã (o que vemos até a Religião nos limites da simples razão de 1793), mas como uma ética da autoformação moral, muito mais vinculada à tradição filosófica grega. 


\section{Parte l: sobre os fins da razão humana}

\section{Fim objetivo da razão e a ideia de virtude como perfeição moral}

Neste artigo discutiu-se, inicialmente, o papel das ideias da razão na ética de Kant e o conceito (e necessidade) de um fim objetivo da razão, que consistiria numa espécie de complemento ao imperativo categórico que, enquanto princípio meramente limitativo, não provê por si só o completo sistema moral, carecendo de um fim que não seja meramente contingente (subjetivo), pois, segundo Kant, se todos os fins são contingentes, o próprio imperativo categórico, que prescreve uma ação como necessária careceria de sentido, haja vista que toda ação visa igualmente um fim. Havendo, assim, a necessidade de se considerar a existência de um fim propriamente moral, necessário em si mesmo. A questão central é saber se é realmente necessário à ética assumir a existência de um tal fim; e, visto que Kant em diferentes momentos do seu pensamento propõe ideias distintas como sendo semelhante fim objetivo (na Fundamentação da Metafísica dos Costumes a ideia de humanidade como fim em si, na Crítica da razão prática e Religião nos limites da simples razão a de sumo bem, e na Doutrina da virtude a de fins que são deveres) investigar qual a razão da incerteza de Kant e se sua proposta final (da Doutrina da Virtude) atende aos requisitos necessários, isto é, se podemos realmente considerar os fins que são deveres como os fins objetivos da razão. A ligação entre estes dois pontos (ideias da razão e fim objetivo) reside no fato de que o conteúdo de tal fim objetivo da razão obviamente é uma ideia, pois a razão só toma como fim moral os objetos das ideias que ela mesma se dá.

Num segundo momento, a discussão versa sobre a colocação do conceito de virtude como sendo o fim moral por excelência, a perfeição moral. Neste sentido, busca-se complementar a discussão do tópico anterior ao explicitar em que medida o conceito de um fim, no caso a virtude (que no fundo é um título geral para a representação dos fins que são deveres) pode servir de complemento ao imperativo categórico. Para tanto, fazemos referência à discussão contemporânea da "ética 
das virtudes" vs. "ética da ação", mostrando que a ética kantiana não pode ser radicalizada para um dos dois lados, sendo uma composição, em que o conceito de imperativo moral tem papel fundamental sim, ao servir de guia e de padrão de julgamento para a ação individual, mas, em contrapartida os fins morais da ação em Kant (em especial o conceito de virtude) também desempenham importante função ao propor um "modo de ser", um modelo de vida.

\section{Santidade e Virtude}

Como disse anteriormente, a moral kantiana trabalha com a tese de que existem perfeições que devemos buscar. Entre essas perfeições encontra-se a perfeição moral. Entretanto, ao longo do desenvolvimento da ética de Kant encontra-se o problema de determinar em que consiste exatamente essa perfeição. Vale dizer, essa perfeição é santidade ou virtude?

Assim, por exemplo, na Crítica da razão pura, falando sobre a ideia de virtude Kant afirma que “[...] ela encontra-se necessariamente a fundamento de toda aproximação da perfeição moral, por mais distantes que possam manter-nos desta perfeição os obstáculos presentes na natureza humana e não determináveis em seu grau" (KrV, B 372). Por outro lado, na Religião nos limites da simples razão ao falar sobre os fundamentos materiais (morais) de determinação do arbítrio (perfeição própria e felicidade dos outros) afirma que se pela primeira se entende perfeição moral, esta só pode ser uma "a saber, uma vontade que obedece incondicionalmente a lei" (RGV 06:4). E esta é, como veremos, a definição de santidade.

Uma saída, talvez, fosse aceitar a tese de que a virtude seria a perfeição moral para o homem enquanto ser racional finito (sensível) e que santidade seria a perfeição para seres racionais perfeitos (como Deus, por exemplo). O próprio Kant afirma isso (cf. KpV 5:128 e TL 6:383). À primeira vista, isso parece correto, pois, como veremos adiante, virtude supõe uma vontade impura, própria dos seres sensíveis, isto é, uma vontade que sofre influência de outros elementos (inclinações, sentimentos, etc), além da razão. Assim, por definição, virtude é para 
seres sensíveis, ou seja, por definição, virtude é a perfeição adequada ao homem. Já a santidade (como veremos com mais detalhe adiante), é entendida como vontade pura o que por definição, exclui a humanidade (bem como qualquer outro ser sensível imaginável) da sua posse. Essa distinção torna-se problemática, contudo, se nos damos conta de que Kant, paradoxalmente, em diversos textos assegura que é um dever para nós humanos buscarmos a santidade, sendo o mandato "Sê santo" lugar comum nos textos de Kant, estando presente em textos desde a década de 1780 como a Crítica da razão prática, onde Kant notadamente se vale de conceitos como Deus, imortalidade da alma e sumo bem, até textos tardios como a Doutrina da Virtude, onde Kant praticamente abole estas pressuposições metafísicas e leva muito mais em conta a natureza humana, como veremos.

Como já disse anteriormente, o presente trabalho, tem como pano de fundo a tese de que há uma sensificação dos conceitos e princípios práticos de Kant (ou, se quiser, da filosofia prática em geral), de modo que há um progressivo abandono de determinados conceitos considerados transcendentes como Deus, imortalidade da alma, natureza como providência, etc., - que bem entendido, eram tomados como princípios regulativos e nunca como realidades - e uma crescente valorização da natureza humana nos escritos tardios. De tal modo que textos como a Doutrina da Virtude, Antropologia de um ponto de vista pragmático, O Conflito das Faculdades, Sobre a Pedagogia, Opus Postumum, embora tratem basicamente dos mesmos problemas práticos levantados em outros textos como Ideia de uma história universal de um ponto de vista cosmopolita, Crítica da razão prática, Sobre a expressão corrente: Isto pode ser correto a teoria, mas nada vale na prática, Religião nos limites da simples razão, À Paz Perpétua, etc.) assumem perspectivas, argumentos e métodos de resolução marcadamente distintos.

Diante disso, a constatação de que o mandamento de buscar a santidade permanece, por exemplo, na Doutrina da Virtude, pode ser tomado como um deslize, vale dizer, uma prova de que Kant não abandona totalmente o seu apego ao transcendente.

Neste sentido, Kant poderia ser acusado de incoerência em dois sentidos: primeiro, por colocar como dever algo irrealizável para o homem; segundo, (em se aceitando essa dinâmica interna, essa evolução 
na filosofia kantiana), por não abandonar (como fez com outros conceitos, como veremos) este conceito quimérico de santidade.

Assim, procuro mostrar no presente artigo que há uma mudança no conceito de perfeição moral que vai no sentido de uma sensificação, de modo que ela deixa de ser pensada como exequível apenas mediante um progresso infinito que supõe a imortalidade da alma, ou um Deus perscrutador de corações (ou seja, enquanto santidade), e passa a depender para sua realizabilidade de uma ascese e de uma didática moral (enquanto virtude). Para isso, num primeiro momento, procurarei apresentar uma alternativa interpretativa para a discussão mencionada acima, partindo da análise da relação entre virtude e santidade na segunda Crítica, posteriormente na Religião nos limites da simples razão, e por último na Doutrina da Virtude, mostrando que em cada um destes textos a relação entre essas perfeições é pensada de modo diferente. Ao longo desse processo, faço uma análise crítica das posições de alguns comentadores acerca desses temas, isto é, da relação entre santidade e virtude, da aceitação da santidade e de outros fins morais (como o sumo bem) como deveres para o homem.

\section{Questões acerca do conceito de virtude kantiano}

Neste artigo procuro discutir a natureza mesma do conceito de virtude apresentado por Kant, bem como alguns problemas levantados pelos comentadores. Em primeiro lugar, procuro discutir principalmente a questão de como compatibilizar a tese de que a conversão moral, a decisão de se tornar um homem bom depende única e exclusivamente de uma revolução no modo de pensar, com a tese de um progresso moral, a tese de que existem graus de virtude.

Com efeito, Kant defende que o indivíduo que segue suas inclinações o faz livremente, e uma mudança no caminho da virtude tem que provir, de uma mudança que é na verdade um ato revolucionário, uma decisão radical, a partir da qual se busca seguir a lei moral em detrimento das inclinações, de forma que não podemos falar de um homem mais ou menos virtuoso, ou que o homem é virtuoso em alguns aspectos e 
em outros não. Esta é a tese rigorista de Kant. Mas se assim é, como podemos falar (como o próprio Kant o faz) em um progresso em direção à virtude? Da mesma forma, Kant defende que virtude é uma ideia e como tal não é possível uma plena realização na experiência, isto é, só é possível ao homem uma contínua aproximação a ela, o que por si só supõe a tese de um progresso moral. Na tentativa de responder a essas questões farei análise de alguns pontos da primeira parte da Religião nos limites da simples razão e de alguns tópicos da Doutrina da virtude, analisando, de modo geral, o conceito de virtude, e especialmente, os conceitos de conversão moral e de progresso da virtude.

Neste sentido, minha proposta é mostrar que a solução a essa suposta incoerência pode estar na percepção daquilo que chamo de as duas dimensões da ética kantiana, a saber, a metafísica e a antropológica.

Na segunda parte do artigo, procuro problematizar acerca de algumas metáforas utilizadas por Kant para definir a natureza do conceito de virtude ou mais, propriamente, o conflito entre a concepção de virtude como batalha da razão versus sensibilidade, que coloca o homem virtuoso como guerreiro ou herói e a concepção de virtude como uma disposição tranquila de alma, que caracteriza o homem como uma espécie sábio. Kant, em diversas passagens, adota indistintamente ambos os modelos sem nunca problematizar acerca da visível contradição que eles apresentam entre si.

Mostrando que tais concepções são provenientes da ética grega antiga, e que, mesmo lá já se tinha percepção do problema de mostrar sua compatibilidade, discuto por quais razões Kant as adota e, no limite, qual é a mais coerente com sua visão de ética e virtude. Para tanto levo em conta algumas interpretações da ética de Kant e outras metáforas usadas por ele, como a da virtude como uma espécie de saúde moral, também incorporada da ética antiga.

\section{0 abandono do conceito de sumo bem no pensamento tardio}

No presente artigo, como o título já indica, procuro explicitar as razões do abandono do conceito de sumo bem no pensamento tardio de 
Kant e apontar quais as implicações que isso traz para sua ética. O caminho que sigo para isso passa primeiro por discutir o status do dever de promover o sumo bem, isto é, responder às questões: faz mesmo sentido pensar que é um dever moral realizar tal fim? A admissão da irrealizabilidade do mesmo implica, como Kant defende no Cânon da razão pura e na segunda Crítica, na admissão de que a lei moral é uma quimera?

E depois, mostrando "que" e "por que" Kant progressivamente vai abandonando tal conceito, ao se dar conta da sua inexequibilidade para o homem (bem como a já discutida modificação no conceito de fim objetivo), procuro explicitar que isto implica uma concepção de ética mais vinculada a considerações antropológicas, sobre a natureza humana, do que com conceitos transcendentes (ainda que entendidos como princípios reguladores ou postulados).

\section{Parte II: a autoformação do homem segundo fins (ideias)}

\section{Ética e sua relação com a antropologia: a autoformação do homem enquanto ser moral}

Neste artigo, o objetivo é mostrar a relação entre ética e antropologia no pensamento tardio de Kant. Argumenta-se que a perspectiva trazida pela antropologia, vale dizer, a ideia de um homem que se constrói a si mesmo é algo extremamente importante e modifica de maneira salutar a ética kantiana. Assim, se procura apresentar o que o texto Antropologia de um ponto de vista pragmático traz de novo se comparado aos outros textos de Kant sobre filosofia moral, que é justamente a apresentação geral do que é dito acima: a perspectiva de um cultivo do homem expresso pela própria definição do objetivo da antropologia, que é lidar com aquilo que o homem "faz de si mesmo, ou pode e deve fazer enquanto ser que age livremente" (7:119); a apresentação do homem como ser racionável (e não racional), um ser em construção, digamos.

Na sequência, de maneira mais específica, busca-se mostrar em que consiste aquilo que o homem "pode e deve fazer de si mesmo" e qual 
a diferença entre esta perspectiva e a simples exposição do que ele deve fazer, mostrando que o domínio do que ele "pode" fazer, consiste na explicitação de exercícios e práticas que visem o seu desenvolvimento seja numa perspectiva ética, pragmática ou técnica, exercícios e práticas os quais estão para além do que ele deve fazer. Posteriormente, procuro fazer uma rápida aproximação entre a referida concepção kantiana de homem e do seu cultivo com as doutrinas contemporâneas do cuidado de si, que igualmente propõem a tese do homem como um projeto, algo em construção, sendo éticas tais como a do Kant tardio, que propõem que o homem livremente autodetermine seu modo de ser.

\section{Educação e autoformação moral ou Educação e natureza humana}

O presente artigo discute as seguintes questões: qual a relação entre ética e educação em Kant? Entre educação e natureza humana? Se Kant considera possível a moralidade mesmo ao entendimento mais comum qual a necessidade de um "cultivo moral" e especificamente de uma educação que desenvolva o homem neste aspecto? Pretendo, a partir daqui, me ater principalmente a estas questões pensando como, segundo Kant, a educação pode contribuir para o crescimento do homem no seu aspecto ético, ou seja, discutindo a ideia de uma educação moral e, para tanto penso que seja necessário considerar a relação entre educação e natureza humana. Após isto, pretendo tornar explícita a relação entre a ética entendida como doutrina da virtude e a pedagogia kantiana.

\section{Autoposição e auto-afecção no pensamento tardio de Kant}

No contexto da definição da ética do Kant tardio como uma ética que propõe a ideia de uma autoconstrução do homem, da tese de que ele próprio determina o seu modo de ser, o presente artigo mostra como isso se dá, a partir a discussão de dois conceitos: autoposição e auto-afecção. 
Neste sentido, em primeiro lugar se faz uma exposição e apreciação de algumas teses apresentadas no Opus Postumum de Kant que ressaltam a diferente abordagem (antropológica) da ética, presente nos seus textos tardios. Isso é feito basicamente pela discussão da ideia de Deus e do novo papel que Kant dá a ela, e do novo papel do conceito de ideias, entendidas como leis do pensamento a partir das quais o homem cria "visões de mundo", isto é, com base nas quais ele constrói a sua realidade, seja numa perspectiva moral, seja numa perspectiva teórica.

Em seguida, se busca explicar com maior detalhe em que consistem os conceitos de autoposição e auto-afecção e qual a importância dos mesmos para Kant. Sendo a autoposição a tese, mencionada acima, de que o homem se constrói a si mesmo e a sua realidade (do ponto de vista antropológico e não metafísico) e a auto-afecção a tese segundo a qual as ideias (que ele mesmo se dá) efetivamente o movem, isto é, o afetam de maneira peculiar (produzindo os sentimentos de respeito e entusiasmo, por exemplo), de modo que elas, as ideias, são entendidas por Kant como "forças motoras".

\section{Considerações finais}

A tese teve como objeto o conceito de fins morais da razão que, como vimos, são múltiplos (sumo bem, virtude, felicidade, santidade, etc). Estes fins são objetos ideias da razão. Estas, por sua vez, são representações de totalidades, de perfeições, daí Kant as definir como a expressão de um maximum. Mas se as ideias, os fins da razão, são perfeições como é possível torná-los efetivos na experiência? Esse problema, como tentei defender, não passou despercebido pelo filósofo, e supõe não apenas o exame das próprias ideias/fins racionais, mas também das suas condições de exequibilidade, isto é, considerações acerca dos executores de tais fins serem capazes de realizá-los, e ainda um exame do processo por meio do qual tais executores tornam efetivos tais fins (ou seja, uma teoria do progresso moral e de suas condições). 
Kant se dá conta de que, para que eu possa afirmar (ou mesmo provar) que os fins morais da razão são exequíveis, não é indiferente a determinação da natureza do agente livre que os realiza e das condições das quais ele dispõe para tanto. Por isso, juntamente com uma doutrina pedagógica, a antropologia (que propõe um estudo da natureza humana nos seus traços que possam obstaculizar ou favorecer a realização da moralidade) é fundamental.

E neste contexto, há uma progressiva substituição ou abandono de fins tais como o sumo bem e a santidade, por fins tais como a virtude (ou fins que são deveres), e, ainda, deixa-se de pensar a realização do sumo bem moral vinculada a um progresso ao infinito que envolve a postulação das ideias de imortalidade da alma e de Deus, e se coloca a natureza desse processo vinculado ao homem no mundo, o terráqueo, por meio de uma ascese. Isso se tratando do progresso moral do indivíduo, pois, no gênero humano, ao fim, auto-imposição de fins é apresentada como uma autoposição (que tem como aspecto subjetivo a auto-afecção, a autodeterminação segundo ideias), a partir da qual se desenvolve o caráter da espécie. É assim que Kant pensa a efetivação dos fins morais no seu pensamento tardio.

Os fins da razão, enquanto ideias, são totalidades incondicionadas, perfeições, como já foi dito. No pensamento tardio de Kant, acresce-se a isso que elas passam a ser entendidas como forças motoras a partir das quais o homem se constrói a si mesmo. A virtude, por exemplo, não é como na KrV uma mera ideia, no sentido de apenas servir como um padrão de medida do julgamento moral e de propor uma disposição de ânimo específica, ou seja, que o homem virtuoso é aquele que domina, pela razão, as suas inclinações e afetos, mas é uma ideia também no sentido de propor um modo de ser que apresenta infinitas possibilidades.

Mas, como compatibilizar isso, que chamo durante o trabalho de tese da plasticidade da natureza humana, de que o seu desenvolvimento é infinito, pois apresenta um horizonte aberto de inúmeras possibilidades e perspectivas para sua autoconstrução, com a tese de que a razão me apresenta fins morais - que são por sua vez deveres? Isto é, se o homem tem uma perfeição moral a buscar, perfeição esta 
que é claramente definida, como pode ele se desenvolver não apenas em graus de aproximação a esta perfeição, mas também com uma indefinida amplitude no campo moral?

A resposta a estas questões está, como tentei mostrar, na adequada compreensão da antropologia em sentido pragmático como o estudo do que o homem "pode e deve fazer de si mesmo". A ética de Kant não apenas diz o que o homem deve ou não fazer, mas vai além disso. No entanto, isso só acontece na medida em que ele se ancora no conceito de virtude como fim máximo moral que, seguindo a tradição grega, representa a busca de um modo de ser que torne a vida (terrena) excelente, porém, não mais os conceitos de santidade e sumo bem que supõem sempre a esperança de um porvir e que, portanto, acabam por representar a vida excelente como uma ruptura com o mundo.

Paradoxalmente a vinculação de Kant à filosofia grega antiga implica uma abertura ao contemporâneo. A ideia de autoprodução, de cultivo de si mesmo, de plasticidade da natureza humana, na filosofia contemporânea encontra amparo na filosofia grega (estóicos e epicuristas). A ética do cuidado de si de Foucault é um exemplo disso. Igualmente, estas concepções que, como tento mostrar, já estão presentes em Kant aparecerão em outras correntes filosóficas contemporâneas, em especial o existencialismo, por exemplo, na ideia de existência humana como um projeto, como um ser que vai se auto-definindo por suas escolhas sem possuir uma essência que o preceda.

A concepção de homem do Kant tardio é, neste sentido, inovadora, mas é preciso marcar algumas diferenças básicas. A ética do cuidado de si de Foucault é tal que se propõe uma ética que esteja para além dos deveres, é pura plasticidade da natureza humana. O existencialismo também pensa o homem como uma construção absolutamente livre de regras. Kant, em contrapartida ainda tem o dever, ainda tem uma razão que representa um traço universal da natureza humana. $\mathrm{O}$ que é plástico na natureza humana está inserido dentro do domínio da racionalidade.

De todo modo, ele atribui um papel quase ilimitado à inventividade humana na construção do seu caráter, no seu processo de autoconstrução. O homem cria ideias e a partir delas vai se auto-fazendo e 
construindo seu mundo. São muitas as ideias possíveis e, portanto, são muitas as visões de mundo, muitos os possíveis "modos de ser". São muitos os fins que o homem pode se dar, pois são muitas as ideias que ele pode pensar, mas ainda há a razão, há fins objetivos, e por isso não podemos dizer que o homem é pura acontecência, puro devir. Em Kant, paradoxalmente, a volatilidade do homem se estriba na própria razão, pois ela é uma capacidade de produzir ideias, fins, ou se se quiser, modos de ser.

Mas, é importante observar também que "Ideias são princípios subjetivos auto-criados do poder de pensar: não ficções, mas pensamentos" (OP 21:29), isto é, ideias mesmo sendo autocriadas não são meras ficções, que envolvem imaginação, dizendo respeito ao domínio estético; elas são produtos da razão, tendo a função de antecipar conhecimentos (OP 21:51) e práticas a partir do já referido processo de auto-afecção.

E graças à razão universal Kant, mesmo nos seus escritos tardios, permanece com a visão otimista da história, própria do iluminismo, vale dizer, com a confiança no progresso: razão e história caminham juntas, não há crise. Mas no pensamento tardio, a tese do progresso é puramente antropológica, é do homem no mundo que se fala; não há propriamente uma escatologia (como a que vemos no progresso moral do indivíduo na Crítica da razão Prática); o que vemos é um descortinar de uma visão de homem como autor da sua própria felicidade.

Rohden, ainda preso à visão de progresso presente na segunda Crítica, opõe Kant aos antigos:

As escolas gregas não chegaram à solução da questão do sumo bem, porque dispensavam a existência de Deus e imaginavam alcançar a virtude plenamente nesta vida [...]. Com isso se excederam em relação à capacidade do homem como sábio, "para além de todos os limites de sua natureza", admitindo algo contraditório em relação ao que conhecemos do homem. (2005, p. 160)

E neste sentido, segundo ele, "Muito mais identificada com a consciência kantiana da finitude humana revelou-se a ética do 
cristianismo, para o que, igualmente, a virtude era aproximação infinita e a felicidade não era totalmente alcançável nesta vida." (Ibidem).

O que procurei defender na presente tese é justamente o contrário, isto é, que no seu pensamento tardio Kant vê o homem sob uma outra perspectiva, mais próxima da filosofia grega antiga, o que implica que, se concordarmos com Rohden quanto à afirmação de que os gregos tentaram igualar o homem à divindade, no sentido de ser capaz de proporcionar a si mesmos a virtude e a felicidade, devemos pensar que o filósofo alemão faz o mesmo, até porque como vemos afirmado no Opus Postumum, Deus est in nobis, ou seja, é uma mera ideia da razão humana.

\section{Referências}

ALLISON, H. Kant's theory of freedom. Cambridge: Cambridge University Press, 1990.

BECK, L. W. A commentary on Kant's critique of pratical reason. Chicago: The University of Chicago Press, 1960.

COPLESTON, F. A history of Philosophy - Vol. VI: Wolff To Kant. London: Search Press, 1977.

ESTEVES, J. C. R. Liberdade e moral em Kant. 1998. (Tese de doutorado), Universidade Estadual de Campinas, Campinas.1998.

GUYER, P. Freedom, law and happiness. Cambridge: Cambridge University Press, 2000.

KANT, I. Antropologia de um ponto de vista pragmático. Trad. Clélia Aparecida Martins. São Paulo: Iluminuras, 2006.

KANT, I. A Religião dentro dos limites da simples razão. Trad. Artur Morão. Lisboa: Edições 70, 2008. 
KANT, I. Crítica da faculdade do juízo. Trad. Antônio Marques e Valério Rohden. 2 ed. Rio de Janeiro: Forense Universitária, 1995.

KANT, I. Crítica da razão prática. Trad. Artur Morão. Lisboa: Edições 70, 1986.

KANT, I. Crítica da razão pura. Coleção Os Pensadores. Trad.Valério Rohden e Udo Baldur Moosburger. São Paulo: Abril Cultural, 1980.

KANT, I. A metafísica dos costumes. Trad. Edson Bini. 2 ed. Bauru: Edipro, 2008. KANT, I. Fundamentação da metafísica dos costumes. Trad. Artur Morão. Lisboa: Edições 70, 1992.

KANT, I. Idéia de uma história universal de um ponto de vista cosmopolita. Org. Ricardo Ribeiro Terra. Trad. Ricardo Ribeiro Terra e Rodrigo Naves. São Paulo: M. Fontes, 1986.

KANT, I. O conflito das faculdades. Trad. Artur Morão. Lisboa: Edições 70, 1993. KANT, I. Opus postumum. Trad. Eckart Förster e Michael Rosen. New York: Cambridge University Press, 1999.

KANT, I. “Que significa orientar-se no pensamento". In: A paz perpétua e outros opúsculos. Trad. Artur Morão. Lisboa: Edições 70, 1993, p.39-55.

KANT, Immanuel. Sobre a pedagogia. Trad. Francisco Cock Fontanella. Piracicaba: Editora Unimep, 1996.

LOPARIC, Z. A semântica transcendental de Kant. 2 ed., revista. Campinas: UNICAMP, Centro de lógica, Epistemologia e História da Ciência. 2002.

LOPARIC, Z. "O fato da razão - uma interpretação semântica". Analytica. v. 4, n. 1, p. 13-55, 1999.

LOUDEN, R. Kant's impure ethics: from rational beings to human beings. New York: Oxford University Press, 2000.

LOUDEN, R. Applying Kant's ethics: the role of Anthropology. In: A companion to Kant. Ed. Graham Bird, Oxford: Blackwell, 2006. p. 350-363.

REICH, K. Kant and Greek ethics. Mind, New Series, v. 48, n. 191, Jul. 1939, p. 338-354. 
ROHDEN, V. A Crítica da razão prática e os estóicos. Revista dois pontos, Curitiba, São Carlos, v. 2, n. 2, p. 157-173, 2005.

SANTOS, R. M. Leis permissivas da razão e o problema das ações moralmente-indiferentes. In: Studia Kantiana. n. 12, p. 64-76, 2012.

SANTOS, R. M. Kant, Foucault e o cuidado de si. In: Kant e-Prints, Série 2, v. 8, n. 2, jul.-dez., 2013. p. 85-101.

FOUCAULT, M. Ditos e escritos - Vol. 5: Ética, sexualidade e política. Org. Manoel Barros da Motta. Trad. Elisa Monteiro e Inês Austran Dourado Barbosa. Rio de Janeiro: Editora Forense Universitária, 2004.

FOUCAULT, M. História da sexualidade - Vol. 3: O Cuidado de Si. Trad. Maria T. da Costa Albuquerque. 8 ed. Rio de Janeiro: Edições Graal, 2005.

FOUCAULT, M. O Governo de si e dos outros, São Paulo: M. Fontes, 2010.

LONG, A. Stoic studies. Cambridge: University Press, 2001.

RIST. J. M. La filosofia estoica. Trad. David Casacuberta. Barcelona: Novagràfik, 1995.

Recebido: 09/06/2016

Received: 06/09/2016

Aprovado: 09/06/2016

Approved: 06/09/2016 